\title{
Palatal development of preterm and low birthweight infants compared to term infants - What do we know? Part I: The palate of the term newborn
} Ariane Hohoff*1, Heike Rabe ${ }^{2}$, Ulrike Ehmer ${ }^{1}$ and Erik Harms ${ }^{3}$

Address: ${ }^{1}$ Poliklinik für Kieferorthopädie, Universitätsklinikum, Westfälische Wilhelms-Universität, Münster, Germany, ${ }^{2}$ Department of Neonatology, Brighton \& Sussex University Hospitals, UK and ${ }^{3}$ Klinik für Kinderheilkunde, Division of Neonatology, Universitätsklinikum, Westfälische Wilhelms-Universität, Münster, Germany

Email: Ariane Hohoff* - hohoffa@uni-muenster.de; Heike Rabe - Heike.Rabe@bsuh.nhs.uk; Ulrike Ehmer - ehmer@uni-muenster.de; Erik Harms - harms@uni-muenster.de

* Corresponding author

Published: 28 October 2005

Head \& Face Medicine 2005, 1:8 doi:10.1 186/1746-160X-1-8

This article is available from: http://www.head-face-med.com/content/I/I/8

(C) 2005 Hohoff et al; licensee BioMed Central Ltd.

This is an Open Access article distributed under the terms of the Creative Commons Attribution License (http://creativecommons.org/licenses/by/2.0), which permits unrestricted use, distribution, and reproduction in any medium, provided the original work is properly cited.

\begin{abstract}
Background: The evidence on prematurity as 'a priori' a risk for palatal disturbances that increase the need for orthodontic or orthognathic treatment is still weak. Further well-designed clinical studies are needed. The objective of this review is to provide a fundamental analysis of methodologies, confounding factors, and outcomes of studies on palatal development. One focus of this review is the analysis of studies on the palate of the term newborn, since knowing what is 'normal' is a precondition of being able to assess abnormalities.
\end{abstract}

Methods: A search profile based on Cochrane search strategies applied to 10 medical databases was used to identify existing studies. Articles, mainly those published before 1960, were identified from hand searches in textbooks, encyclopedias, reference lists and bibliographies. Sources in English, German, and French of more than a century were included. Data for term infants were recalculated if particular information about weight, length, or maturity was given. The extracted values, especially those from non-English paper sources, were provided unfiltered for comparison.

Results: The search strategy yielded 182 articles, of which 155 articles remained for final analysis. Morphology of the term newborn's palate was of great interest in the first half of the last century. Two general methodologies were used to assess palatal morphology: visual and metrical descriptions. Most of the studies on term infants suffer from lack of reliability tests. The groove system was recognized as the distinctive feature of the infant palate. The shape of the palate of the term infant may vary considerably, both visually and metrically. Gender, race, mode of delivery, and nasal deformities were identified as causes contributing to altered palatal morphology. Until today, anatomical features of the newborn's palate are subject to a non-uniform nomenclature.

Conclusion: Today's knowledge of a newborn's 'normal' palatal morphology is based on nonstandardized and limited methodologies for measuring a three-dimensional shape. This shortcoming increases bias and is the reason for contradictory research results, especially if pathologic conditions like syndromes or prematurity are involved. Adequate measurement techniques are needed and the 'normal palatal morphology' should be defined prior to new clinical studies on palatal development. 


\section{Background}

Preterm infants, i.e. those born before completion of 37 gestational weeks, account for $6-10 \%$ of births in Western society [1-3]. Preterm infants form the majority of low birthweight infants [3]. By definition, neonates weighing less than $2500 \mathrm{~g}$ are described as low birthweight infants [4]. The proportion of neonates weighing less than 1500 $\mathrm{g}$ (very low birthweight) is approximally $1-1.5 \%$ of all newborns [3]. As preterm infants $<1500-1800 \mathrm{~g}$ and
$<32 n d$ - 34th gestational week have an insufficiently developed sucking response, they normally have to be fed through an orogastric tube.

The factors discussed as potential triggers of a premature birth include: high or low age of the mother, low socioeconomic status, inadequate antenatal care, drug, alcohol and nicotine abuse, diabetes, multiple pregnancies [5], anemia, previous miscarriages or abortions, deformity of

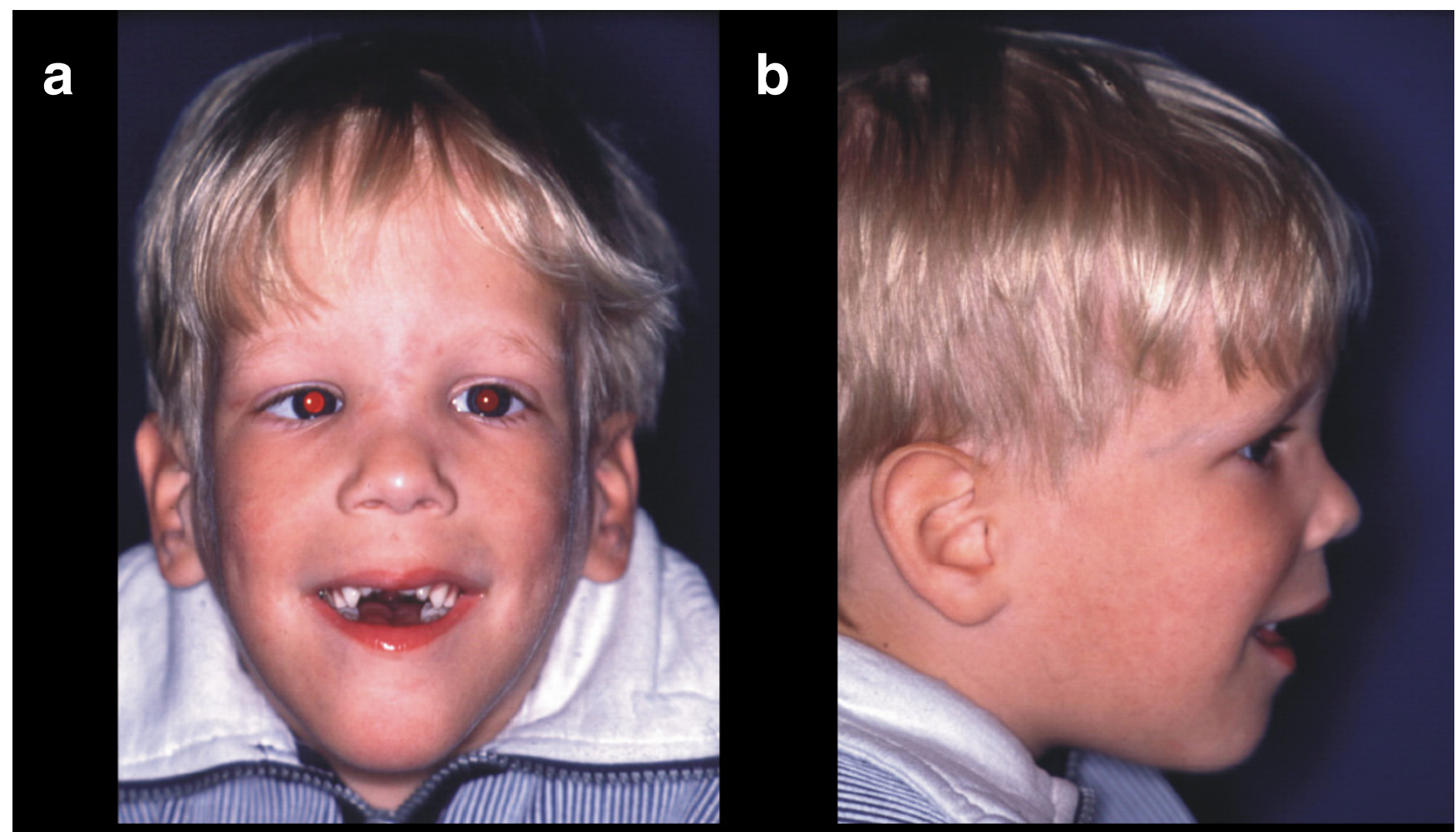

\section{C}
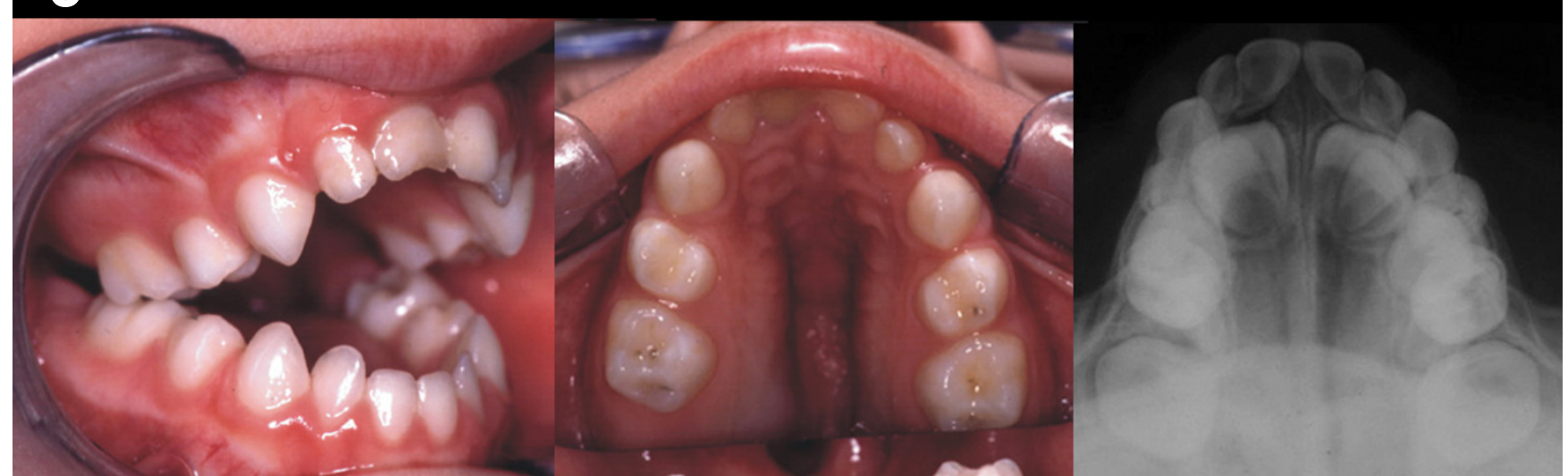

\section{Figure I}

a-e Facial appearance (a, b), circular open bite (c) and palatal aspect (d) of a postnatally orotracheally intubated preterm infant in the initial phase of the dentition. Notice that the teeth of the child are 'in occlusion' on Figures a-c. The food intake - limited to soft or mashed foods due to the extreme dysgnathia - leads to marked frustration. The infant is teased because of its eating problems and the shape of its jaw and head. Radiography revealed premature ossification of the median suture (e). 
the uterus, abnormal presentation of the fetus, endocrine disorders, excessive mental or physical strain on the pregnant woman [6], stress [7], hypertension [8], and infections [9]. The potential influence of periodontal infections in the mother on the risk of a premature birth is a matter on which there is no general agreement: Many studies report an increased risk [10-14] whereas others found no evidence of such an association [15].

Preterm infants suffer not only from the effects of a shorter antenatal development period but from the immaturity of their organs [4], involving the risk of neonatal complications such as immaturity of the liver and kidney vitamin $\mathrm{d}$ metabolism $[16,17]$, pulmonary diseases, hyperbilirubinemia and hypocalcemia [18] as well as respiratory distress, apnea, hypoglycemia, cardiac defects, infections, metabolic bone diseases and intracranial hemorrhages [19]. The latter have a significant impact on the function of rooting, non-nutritive sucking and suck-swallow responses [20].

Longitudinal studies confirm that the physical and cognitive development of most VLBW infants is delayed [2124]. The median incidence of cerebral palsy is $7.7 \%$, and that of disability $25 \%$ [23]. Real chances of survival without a substantially impaired state of health are not to be expected before completion of the 25th - 26th gestational week. Although substantial health impairment is to be expected in $2 / 3$ to $3 / 4$ of infants born in the 24 th gestational week, the survival rate is meanwhile $50-60 \%$, and in those born in the 25th GW as high as $70-80 \%$ [3].

With the survival prospects of preterm infants having undergone such a dramatic improvement [2,25-29], research into the development of these small patients can and must now be extended beyond securing their mere survival to other areas such as their physical and cognitive development. The morbidity potential associated with the premature birth needs to be investigated [30-32]. Only if the problems resulting from premature birth are exactly known preventive measures can be taken.

The orofacial region plays an important role in the infant's development in general: the mouth has been described as the 'cockpit of the awareness of the term infant and of its most discriminate responses' [33]. However, in the early stages of the development of the oral cavity, the soft bones of the palate are malleable and pressure from any object can easily mould the shape of the palate [34]. Thus, at an early stage the palate in particular may be subject to influences such as mode of delivery [35], positioning and gravitational forces [2], oral intubation, sucking respectively inadequate sucking response, delayed primary tooth eruption or general hypotonia and its development may in turn affect the infant's food intake, breathing, phonation, dental development, facial appearance [2], esthetics and psychosocial development (Figure 1a-e).

The evidence of these consequences is still weak. A recent published systematic review [36] could not answer the questions on whether premature birth causes permanent alteration of palatal morphology, alteration of dental occlusion, and altered tooth-crown dimensions. The scientific evidence was too weak because of the contradictory results and lack of longitudinal studies.

Systematic reviews are not subject to the weakness of conventional narrative literature reviews because of the defined methods used to identify and reject studies; therefore, the conclusions are more reliable. However, systematic reviews are also open to questioning. The main issue to which criticism is addressed is the oversimplification of results by focusing on overall effects and downplaying mediating effects [37]. Contradictory results and methodological heterogeneity are common problems in the constitution of a systematic review. Six out of seven recently published systematic reviews (PubMed search: 'systematic review' AND orthod*) [36,38-43] concluded - irrespective of the research question - that further well-designed studies are needed.

It is therefore necessary to provide prospective investigators with methodological details of previous studies, especially in the field of morphometric assessment of palatal development, where new and more accurate methods have been established in the recent past. Moreover, information in different languages and without a restriction to particular databases and time periods must be included a precondition which has not been considered yet.

The objective of this review is to provide a fundamental analysis of methodologies, confounding factors, and outcomes of studies on palatal development of preterm and low birthweight infants as compared to term infants. This review will be a major source of unfiltered data from more than a century, including also literature in German and French.

\section{Methods}

The research was conducted according to the proposals of Greenhalgh $[44,45]$ and the search strategies of the Cochrane Oral Health Group, the Cochrane Neonatal Group, the Cochrane Pregnancy Group and the Cochrane Childbirth Group were applied. As a recent paper pointed out the truncation of orthodontic* as suggested by the Cochrane Oral Health group to be entailing the implicit exclusion of relevant articles [46] other search strategies were used in addition to those of the Cochrane groups: (((child* OR infant* OR (low birthweight) OR neonate* OR premature* OR preterm*) AND (alveol* OR gum* 
OR palate* OR maxill* OR orthodon* OR groov*)) NOT (syndrom* OR cleft* OR cancer* OR carcino* OR fract* OR traum* OR surg* OR infect* OR occlusion* OR malocclusion* OR laser* OR (orthodontic treatment) OR caries OR lung OR cell OR cancer [sb] OR space [sb] OR cam [sb] OR tox [sb] OR history [sb] OR aids [sb] OR letter [pt])) Field: Title/Abstract, Limits: All Child: 0-18 years, Human.

Electronic literature research comprised the following medical databases: AMED, BIOSIS, CareLit, Cochrane Library, Current Contents, EMBASE, KindHeilk, Oldmedline, Pubmed, Web of Science. Additionally, 'hand search' was performed in text books and encyclopedias relevant to the subject, and in the following journals, including supplements and abstract bands: Clinics in Perinatology, vol. 21-30 (1994-2003); Der Kinderarzt vol. 16-21 (1985-1990) and vol. 25-31 (1994-200); Der Kinder- und Jugendarzt vol. 32-33 (2001-2002); Kinderärztliche Praxis vol. 53-61 (1985-1993) and 6873 (1997-2002); Pediatric Clinics vol. 32-50 (19852003); Pediatric Research vol. 19-33:1 (1985-1993), 33:3-52 (1995-2002) and Pediatrics vol. 75-110 (19852002). Retrieved publications were checked for references and, where appropiate, these publications found in the bibliographies were considered in the review.

\section{Selection criteria}

Sources in English, German and French were included from 1900 to 1/2004: non-metric visual findings, metric studies with intraoral measurements if no absolute numerical data were given but only visual findings were expressed in relative terms, and metric studies on plaster casts made from impressions of the palate. Only data provided in the reports were considered, and no attempt was made to contact the authors for missing or 'raw' data, because our research reached back to the beginning of the last century so that it would not have been possible to contact all authors.

As the authors of the review had been strongly involved in the subject matter, it was not possible to 'blind' them for the studies. Titles and/or abstracts of all citations were screened by one author (AH). In cases of doubt, the inclusion or exclusion of studies was discussed, and consensus was reached, among all authors. The full text of all relevant studies was evaluated. Exclusion criteria and affected studies are listed in Table 1 (see Additional file 1).

\section{Results}

The electronic search strategy resulted in 141 articles, six abstracts, four conference papers, eight letters, six dissertations, and two masters theses. By hand search, eight abstracts, six bookchapters, and one encyclopedia were identified. Twenty-eight studies were excluded (Table 1, see Additional file 1) and one hundred fifty-five articles remained for final analysis. Among these, one hundred nineteen studies assessed morphometrically the development of the palate.

The first identified study was published in 1934 [47]. Looking at the different publication years and the different research questions, the articles can be divided into two parts: morphology of the preterm palate and morphology of the term newborn palate. The latter research topic was of great interest before 1960, whereas research on the preterm palate had its peak in 1985 .

A further pattern to classify the research is the general methodology used for morphological assessments. Two different approaches could be identified for both groups, term and preterm infants: visual descriptions and metrical descriptions of the palatal configuration. Therefore, the review presented here follows the given patterns of past research and is divided into two parts.

Part 1 summarizes the applied descriptions of the palate in the term newborn. Without knowledge of the term infant's normal oral structures, it would be impossible to recognize abnormalities in the preterm infant's palate. The review of papers and bookchapters using visual descriptions of the term infant's palate - which are important for a general overview for the clinician - is followed by a presentation of metrical studies, which are necessary to validate clinical impressions which are the major source for measurements. The analysis of the studies is therefore ordered as follows.

- Visual description of the palatal configuration of the term newborn

- Palatal configuration with respect to gender and race

- Metric description of the palatal configuration of fullterm infants

- Palatal configuration with respect to gender and race

- Palatal configuration with respect to cranial index

- Palatal configuration with respect to mode of delivery

- Palatal configuration with respect to nasal deformities

\section{Visual description of the palatal configuration of the term newborn}

In the newborn, the jaw already displays the palatine rugae present in the adult as well as the frenulum and the incisive papilla. In most cases the frenulum, which is located between the lip and the incisive papilla, recedes. If 


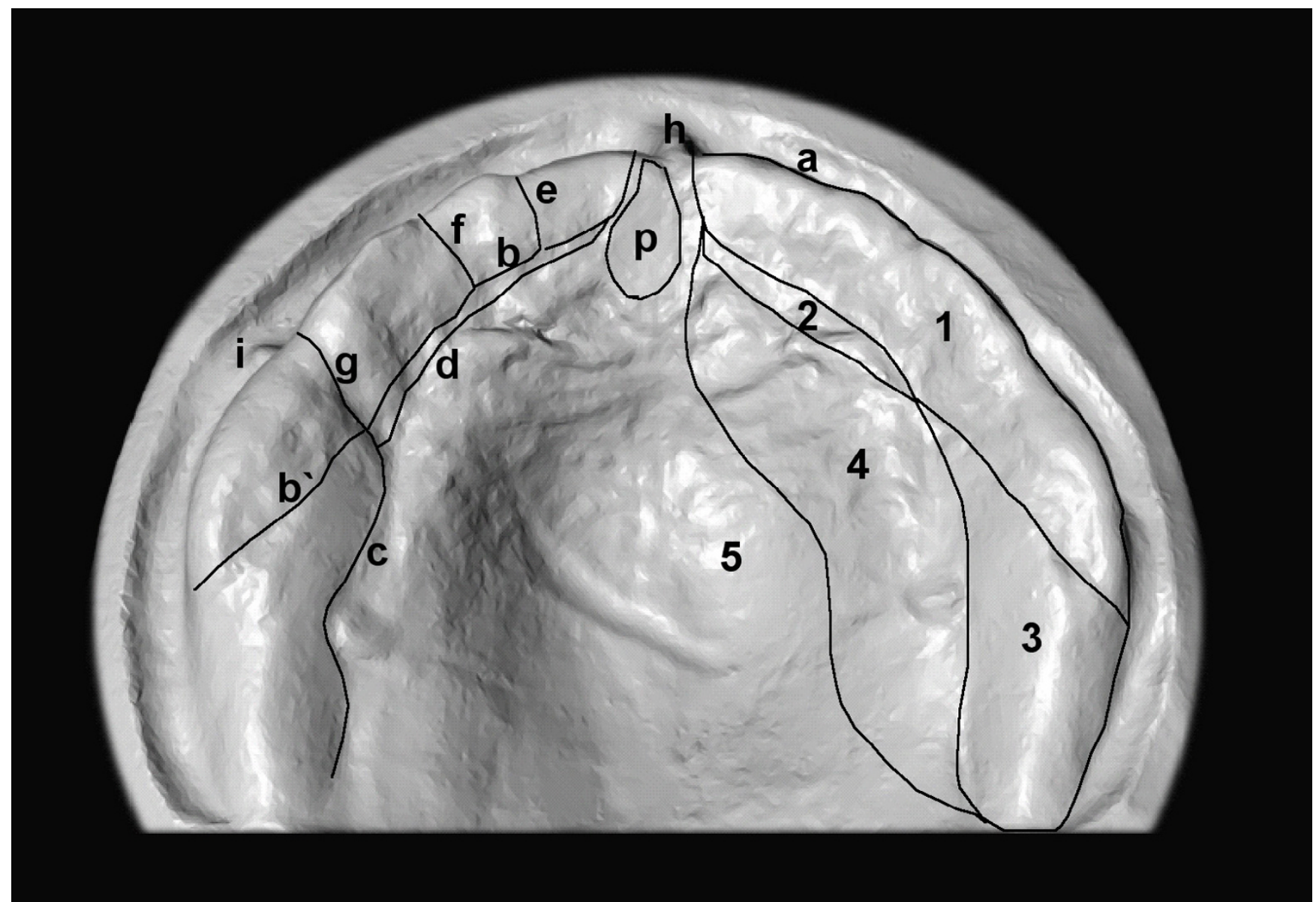

Figure 2

The alveolar portion of the upper gum pad is separated from the palate by a groove. The alveolar portion itself is again divided into buccal and lingual portions which are also separated by grooves. The former is the larger, participates in the formation of the sheath and socket of the teeth, and is further divided by transverse grooves or sulci into segments corresponding to the developing tooth germs. For nomenclature of palatal structures, see Table 2 (Additional file 2). Interestingly, the 'Terminologia Anatomica' contains for discription of palatal structures only the following terms: Frenulum labii superioris (Frenulum of upper lip); Palatum (Palate); Palatum durum (Hard palate); Palatum molle, Velum palatinum (Soft palate); Raphe palati (Palatine raphe); Plicae palatinae transversae, Rugae palatinae (Transverse palatine folds; Palatine rugae); Papilla incisiva (Incisive papilla).

it fails to do so, it is known as a persisting tectolabial frenulum, which may later give rise to a midline diastema [48].

In addition to the structures present in the adult, however, the maxilla of the newborn is characterized by a special feature: the groove system (Figure 2). This separates clearly visible maxillofacial regions and valla from one another and, like the frenula, is subject to a non-uniform nomenclature [49]. According to an investigation on palatal casts of 500 newborn fullterm children, the maxillary alveolar arch is marked along its whole length by the dental groove which divides it into two parts, a lateral labiobuccal and a medial lingual portion; it is through the former of these that the teeth eventually erupt [50] (Figure 2 ). The gum pad is divided into ten segments [51] which correspond to the developing tooth germs [50]. The central incisor and canine segments are approximately equal in size and are well marked; they are separated from the smaller lateral incisor segment, which is indistinct and sometimes lies lingual to them, by two shallow grooves. The lateral sulcus runs anteriorly from the lingual to the labial aspects and sometimes extends to a lateral frenum, this sulcus is the anterior margin of the first deciduous molar segments, which are the largest [51]. The second molar segment is more difficult to recognize. Merging with the dental groove, it can be made out lying somewhat lingual to the first molar segment. The gum is solid and firm throughout. In the distal part of the maxilla, the pseudoalveolar ridge can be recognized, a transient structure, which disappears in the first months of life (Figure 2). 
What is of greatest importance within the framework of the present review is - as discussed in Part 3: 'consequences of intubation' - the most palatally located vallum (synonyms: tectal vallum, tectal ridge, lateral palatine ridge, lateral alveolar ridge, lateral palatine prominences or lateral palatine processes; see Figure 2, Table 2 (see Additional file 2)), which is a normal structure in the neonate and does not have an osseous but rather a connective-tissue base [52]. Hanson et al. reported after examining three deceased and 260 normal infants [52]: 'During early fetal life the lateral palatine ridges are composed of loose mesenchymal tissue with collagenous fibers embedded in lightly PAS-positive matrix. Alcian blue staining confirms the presence of acis mucopoloysaccharide. As development progresses the connective tissue become more dense, and the ridges appear less prominent in relation to the adjacent structures. As a result of the smoothing of the palatal vault and continued growth of the alveolar ridge, the lateral palatine ridges are less prominent in the normal full-term infant than in earlier stages.'

Although there are obvious growth changes, the gum pad shows similar features at six months of age [25] (Table 3, see Additional file 3 ). Probably due to tongue thrust into the palatine vault [53], there is then a marked flattening of the lateral palatine ridges in the second year of life [52]. In the vast majority of the normal children ( 48 out of 56) the lateral palatine ridges are no longer apparent at the age of five years [52]. The configuration of the palate is then similar to that observed in adults.

Klemke [54] reported in his study on 200 newborns various kinds of upper jaws: a nearly semicircular form, a shape with a flattened anterior part and a nearly eleptic arch (percentages not given) (Table 3, see Additional file 3). In accordance, Neumann [55] described individual variations in palatal shape of 200 newborns, the majority of children, however, having horse-shoe or u-shaped palates (no percentages given) (Table 3 , see Additional file 3 ). Approximately $1 / 3$ of her probands presented a parable shape. Ott [56] diagnosed characteristic changes with respect to palatal shape in the course of time: up to the age of twelve months the majority of jaws had a semicircular anterior form with convergent sides, from 16 to 24 months parallel sides, and from 28 to 32 months divergent sides. She interpreted those changes in connection with the tooth eruption. The reliability of the method was not given in all three dissertations [54-56] (Table 3, see Additional file 3).

All elements of the bony palate are present in the fullterm neonate. The median palatine suture is a firm, fibrous articulation without fusion. The transverse suture between the palatine process of the maxilla and the intermaxillary bone is usually open and closes during the first year [57].
The palate during the first year of life is relatively broad and flat [58].

Epstein's Pearls, currently called palatal cysts [59] are remnants of epithelial tissue trapped during the palatal fusion. Their general incidence has been reported to be around $65 \%$ in full term newborns $[60,61]$. Bohn's nodules are remnants of mucuous gland tissue found on the buccal or lingual aspects of the dental ridges, dental lamina cysts (glands of Serres) are found along the crest of the alveolar ridges, both together are currently called alveolar cysts, and have also been referred to as 'gingival cysts' or 'inclusion cysts' [59]. An incidence of 36\% of maxillary alveolar cysts in 1 - 5 days old full term newborns is reported [60]. The clinical description of palatal and alveolar cysts varies in color from white, to gray to yellow nodules, in size from a pinhead to $3 \mathrm{~mm}$, and in numbers from 1 to 6 [59].

\section{Palatal configuration with respect to gender and race}

According to Dittrich [62] in newborn infants of both sexes the predominant form of the upper jaw is that with semicircular anterior parts and converging sides (male: $62 \%$, female: $66 \%$ ), followed by that with parallel sides (male: 18\%, female: 2\%). In contrast, Oelschlaegel [63] found a significant higher percentage of girls (62\%) with a semicircular anterior part of the palate than boys (51\%), and observed in boys among all possible forms of the side the parallel form to be the most frequent. In neither of the studies the reliability of the method was given, nor was mentioned explicitely that term infants had been examined. Leighton and Seshadri [64] found in a sample of 34 Caucasian full term infants at birth in only $14.7 \%$ midline notching of the upper gum pad compared to 34 matched Afro-Carribean infants, who had in $67.6 \%$ of the cases midline notching. The distribution of sexes in the sample was not given.

Huddart and Graf [65] also revealed differences between English, Italian and Swiss babies, affecting principally the anterior part of the upper gum pad and the contour of the palate. In a study with 500 normal full term newborns ( $82 \%$ blacks, $18 \%$ whites) from in the majority economically disadvantaged mothers aged less than 25 years in an urban setting (none of the babies had been admitted to the intensive care unit) a total of $21 \%$ alveolar notches was found. Those notches were significantly more common in blacks, with an odds ratio of 2.7 (a definition of the notches and their grades of severity was not given) [66]. There is speculation that notching is associated with a midline diastema in the primary and permanent dentition $[61,67]$.

Friend et al. [66] found in 58\% of the above mentioned sample cysts within the median raphe or the hard palate 
(Epstein pearls) or palatal cysts, which were defined by the authors as Bohn's nodules, i.e. whitish nodules at the junction of the hard and soft palate adjacent to the midpalate raphe (n.b. the different terminology in comparison to Donley et al. [59]). Most of the lesion in series were found at the hard-soft palate juncture. Midpalatal cysts were 2.5 times more likely to occur in white newborns $(75 \%)$ than in blacks $(55 \%)$. With respect to mentioned palatal structures, no gender difference was found.

Monteleone and McLellan [68] described results similar to those of Friend et al. [66]. The former found palatal cysts in $85 \%$ of the white children in contrast to $79 \%$ of the black children. With respect to palatal and alveolar cysts, Donley and Nelson [59] did not find significant differences between a cohort of caucasian children and a group of non-caucasian infants established from black, Latino and Indian children. Nor did they find gender differences.

Friend et al. [66] found no palatal cyst in the premaxillary region, all were posterior to the incisive foramen, which might be explained by the fact that the premaxilla is the first portion of the palate to fuse, if the pathogenesis of these lesions depends on entrapment of epithelium during fusion of the palatal shelves [69]. Alveolar cysts (grayish-white nodules along the crest of the alveolar mucosa or, less commonly on the lingual or facial borders) also were more likely in whites $(26 \%)$ than in black children (11\%, odds ratio 3.3 , no distinction between upper and lower jaw was given).

Jorgenson et al. [61] found a higher total incidence in both races, but also diagnosed more alveolar cysts in whites (53\%) than in blacks (40\%). Although palatal and alveolar cysts are similar clinically and histologically, the former were more common, a discrepency which might be explained by the histopatholic presence of alveolar cysts in stillborns with lacking clinical manifestation [60].

Alveolar lymphangioma (blue, domed, fluid filled lesions on the alveolar ridges of either arcade, which occur typically bilaterally) was only found in black children, with teenage mothers at enhanced risk of having a child with this condition [66]. The latter authors found in none of the mentioned parameters a predeliction in gender, nor did Donley and Nelson [59].

\section{Metric description of the palatal configuration of fullterm infants}

In order to validate clinical impressions, there is a need for measuring palates. Manufactureres would benefit from metric information to design save products [70].
Valid, plaster cast-based metric descriptions of the palatal configuration of healthy, term children around birth and in the first years of live are, however, rare (Table 3, see Additional file 3; Part 2: Table 4, see Additional file 4 of Part 2). Additionally, the following difficulties occur: in only four studies is named explicitely that term infants have been examined $[25,50,67,71]$; in two further studies, weight and/or maturity of the included children were given, enabling the authors of the review to recalculate the data for term infants; only eight studies $[25,51,54,55,58,59,67,71]$ provided data on the weight and/or body length of the probands. Thus, the comparability of the results is limited.

The form of the upper jaw can considerably vary [54]. By recalculation of original data for term infants a correlation between maximum palatal width and weight, length of body, and biggest head circumference could be found ( $\mathrm{p}$ $<.05)[54]$.

In contrast, Leighton observed a low correlation $(r=0.4)$ between the dental arch width of neonates and their birthweight [67]. He moreover detected in a comparison of monozygotic twins, dizygotic same-sex twins and dizygotic different-sex twins that the differences in palatal width were twice as large in the last group as in the first. The author interpreted this as an indication that palatal width is genetically determined. Although genetic influence was clearly an important factor in determining gum pad morphology, there was only a weak correlation of size between the contained deciduous tooth crowns and the upper gum pad in the newborn [67], which may be due to the thick pad of fibrous tissue overlaying the developing tooth germ [25]. At the age of six months, however, the sum of the upper tooth diameters correlates significantly with maximum palatal width and postgingival width, as does weight. The size of the alveolar process is more linked to tooth size, whereas the total size of the gum pad, and the palate in particular, is more closely related to bodyweight. Sucking habits show a small but significant correlation with the stated palatal parameters, too, suggesting that a sucking habit is associated with narrowing of the palate, without its area or anterior length being altered. Age showed no significant correlation. In addition, the twin-based research revealed a significant hereditary influence on palatal width at birth [64]. A significant heriditary influence on the postgingival width was determined in a comparison of approximately 6-month-old identical twins versus fraternal, dissimilar-sex twins, but not versus fraternal, same-sex twins [25].

In six infants a pronounced transversal growth in the first six months of life was described, wheras a sagittal growth about zero was reported [72]. In contrast, in a study with 428 children, maximum palatal width and maximum pal- 
atal length grew at about the same rate in the first year, the width-length index remaining unchanged during the first year. Palatal height increased until 9 months, then remained quite constant up to the first year. The palatal dimensions varied widely during the first year, by about $7 \%$ for the width and length dimensions and by about 10 $-12 \%$ for maximum height (percentage variability means the coefficient of variation, i.e. the standard deviation divided by the means, times 100) [58]. A continuous increase in mean maximum palatal width of on average $7.45 \mathrm{~mm}$ from birth was measured $(30.99 \mathrm{~mm}$, value taken from [62]) to 32 months of age $(38.44 \mathrm{~mm})$, with the least changes occuring from $12-28$ months [56]. The increase of mean length of the upper jaw was $9.18 \mathrm{~mm}$ (from 24.58 $\mathrm{mm}$ to $33.76 \mathrm{~mm}$ ) (measurements from the beginning of the labial frenulum to a connecting line between the tubera).

\section{Palatal configuration with respect to gender and race}

The existence of ethnic differences could be important to those responsible for overseeing oral development of neonates in populations containing members of different ethnic groups.

Significant greater widths in the anterior part of the gum pad of 34 Afro-Carribean full term infants compared to 34 Caucasian full term subjects have been described [67]. No significant differences neither in the width of the gum pads distal to the lateral sulci nor in palatal height were detected. The differences in height only achieved statistical significance when expressed as the ratio of maximum width to palatal height. Unfortunately, the sex of the sample was not given so that the differences in size could have been wrongly attributed to races but could indeed have also occured due to gender differences: another study reveals the anterior parts of the upper arch of 7-12 years old girls to be smaller, but the posterior parts to be wider than those of the boys [73].

By recalculating the figures given by Neumann [55] no significant gender differences with respect to palatal width were found by the authors of the present review for spontaneously delivered term children aged 1-7 days, matched for birthweight and size (occipito-anterior vertex presentation exclusively). This is in contrast to the results given by the author herself, who found a significant sex difference for palatal width, but who did not distinguish between term and preterm children, included children up to three weeks of age, and did not consider the mode of presentation. Correlations between palatal width and size or birthweight could not be found, either, which is in accordance with the original results given by Neumann [55], and means that newborn children of the same size and birthweight can have differently dimensioned palates. The correlation coefficients for maximum palatal width and length with bodyweight and total body length in 100 male newborns were shown to be of low order (between 0.37 and 0.56), as the palatal dimensions are poorly correlated with each other and with other body dimensions. The palatal dimensions in the male are on average larger than in the female, corresponding to the larger mean size of male newborns [58].

Dittrich [62] and Oelschlägel [63] found significantly wider palates in boys compared to girls, the latter also significantly deeper palates in boys. Oelschlägel [63] did not find any gender differences for palatal length. In contrast, Dittrich measured significantly longer palates in boys [62]. This is in accordance with Hall et al. [48], who found the gender-related difference in palatal length to be accentuated with increasing age (reference values for palatal length, height and width are not given until the age of 5).

\section{Palatal configuration with respect to cranial index}

No correlation between cranial index (biparietal diameter in percentage of frontooccipital diameter) and palatal index (breadth in percentage of length) was found in 515 boys and 455 girls [63].

\section{Palatal configuration with respect to mode of delivery}

Every baby is subject to a certain amount of pressure during parturation, with head adaptations such as parietal bone and facial molding. Any molding of the face occurs across the maxilla, because the bimalar span is the widest part of the face. This molding compresses and deforms the soft maxilla, resulting in possible elevation of the arch of the palate [74].

No significant differences in palatal lengths, depths and widths dimensions between infants with spontaneous vertex presentation $(\mathrm{n}=89$, age 8 days, $>3.4 \mathrm{~kg})$ and children with high or low forceps delivery ( $\mathrm{n}=10$, age 8 days, $>3.4 \mathrm{~kg}$ ) were described [51]. Klemke [54] and Hofbauer [75] did not detect an influence of mode of delivery on the jaws, either. Data for elective caesarian section and spontaneous face presentation was to small to draw any conclusions $[51,55]$.

\section{Palatal configuration with respect to nasal deformities}

Kent et al. [71] tested the hypotheses made by Gray [76] that pressures in the maxilla during birth may cause elevation in one side of the palate and thus asymmetry of the hard palate which in turn could distort the vomer and septal cartilage. The former authors found no evidence of palatal asymmetry (Table 3, see Additional file 3) in 14 out of 500 children compared to 14 controls within three days of birth. The method of measurement was, however, quite coarse and the reliability of the method not given. 
In contrast, at ages $3-6$ years $(\mathrm{n}=145)$ [74], $5-6$ years $(\mathrm{n}=145)$ and again in children 'aged about 8 years' $(\mathrm{n}=90)$ [77] statistically significant more often palatal asymmetries were found in children whose nasal septae were not in the midline at birth. In both studies, height of the palate was related neither to the evenness respectively unevenness of the palate nor to the type of septal deformity $[74,77]$. However, palatal asymmetry of width and height was present statistically significant most frequently in septae kinked to one side, less by septae deviated to both sides and least by straight septae. The method of measurement and the error of the method were not given in either of the two studies.

\section{List of abbreviations}

$[\mathrm{PT}]$ preterm infant, [BW] birthweight, [LBW] low birthweight, [NBW] normal birthweight, [VLBW] very low birthweight, [NBW] normal birthweight, [GA] gestational age, [GW] gestational weeks, [NS] not significant

\section{Competing interests}

The author(s) declare that they have no competing interests.

\section{Authors' contributions}

AH designed the study, searched the databases, extracted the data, analyzed the results and wrote the manuscript. HR helped with study design, analysis and provided critical input in neonatal associated issues and revised the manuscript. UE and EH formulated the research question, helped with study design, analysis and in revising the manuscript. All authors read and approved the final manuscript.

\section{Additional material}

\section{Additional File 1}

Table 1. Excluded studies and reasons for exclusion.

Click here for file

[http://www.biomedcentral.com/content/supplementary/1746-

160X-1-8-S1.pdf]

\section{Additional File 3}

Table 3. Studies on plaster casts.

Click here for file

[http://www.biomedcentral.com/content/supplementary/1746-

160X-1-8-S3.pdf]

\section{Additional File 2}

Table 2. Nomenclature of palatal structures as presented in Figure 2. Click here for file

[http://www.biomedcentral.com/content/supplementary/1746160X-1-8-S2.pdf]

\section{Acknowledgements}

We thank Fiona Lawson for the English language revision.

\section{References}

I. Usher R: The special problems of the premature infant. In Neonatology: Pathophysiology and Management of the Newborn 2nd edition. Edited by: Avery G. Philadephia: JB Lippincott; 198I.

2. Seow WK, Masel JP, Weir C, Tudehope DI: Mineral deficiency in the pathogenesis of enamel hypoplasia in prematurely born, very low birthweight children. Pediatr Dent 1989, I I:297-302.

3. Garbe W: Das Frühchen - Buch Stuttgart: Thieme; 1997.

4. Fearne JM, Brook AH: Small primary tooth-crown size in low birthweight children. Early Hum Dev 1993, 33:81-90.

5. Evaldson G, Lagrelius A, Winiarski J: Premature rupture of the membranes. Acta Obstet Gynecol Scand 1980, 59:385-393.

6. Klinisches Wörterbuch: Psychrembel. In 256th edition. Berlin: W de Gruyter ; 1990.

7. Copper RL, Goldenberg RL, Das A, Elder N, Swain M, Norman G, Ramsey R, Cotroneo P, Collins BA, Johnson F, Jones P, Meier AM: The preterm prediction study: maternal stress is associated with spontaneous preterm birth at less than thirty-five weeks' gestation. National Institute of Child Health and Human Development Maternal-Fetal Medicine Units Network. Am J Obstet Gynecol 1996, I 75: I 286-1292.

8. Walker BR, McConnachie A, Noon JP, Webb DJ, Watt GC: Contribution of parental blood pressures to association between low birth weight and adult high blood pressure: cross sectional study. BMJ 1998, 3 16:834-837.

9. Hillier SL, Nugent RP, Eschenbach DA, Krohn MA, Gibbs RS, Martin DH, Cotch MF, Edelman R, Pastorek JGn, Rao AV: Association between bacterial vaginosis and preterm delivery of a lowbirth-weight infant. The Vaginal Infections and Prematurity Study Group. 1995.

10. Boyd DL, Katz V, Ferktik GS, Offenbacher S: Relationship between periodontal disease status and birth outcome [abstract]. J Dent Res 1994, 73:s394.

II. Collins G, Windley HW, Arnold RR, Offenbacher S: Effects of a Porphyromonas gingivalis infection on inflammatory mediator response and pregnancy outcome in hamsters. Infect Immun 1994, 62:4356-436I.

12. Windley HW III, Collins JG, Arnold RR, Offenbacher S: Molecular mechanisms of $P$. gingivalis-induced pregnacy abnormalties in hamster model [abstract]. J Dent Res 1994, 189:s702.

13. Offenbacher S, Katz V, Fertik G, Collins J, Boyd D, Maynor G, McKaig $R$, Beck J: Periodontal infection as a possible risk factor for preterm low birth weight. J Periodontol 1996: I 103-I II3.

14. Lopez NJ, Smith PC, Gutierrez J: Higher risk of preterm birth and low birth weight in women with periodontal disease. J Dent Res 2002, 81:58-63.

15. Davenport ES, Williams CECS, Sterne JAC, Murad S, Sivapathasundram V, Curtis MA: Maternal periodontal disease and preterm low birthweight: case-control study. J Dent Res 2002, 8 I:3 I3-8.

16. Kovar IZ, Mayne PD, Robbe I: Hypophosphataemic rickets in the preterm infant; hypocalcaemia after calcium and phosphorus supplementation. Arch Dis Child 1983, 58:629-63I.

17. Seino $Y$, Ishii $T$, Shimotsuji T, Ishida M, Yabuuchi H: Plasma active vitamin $D$ concentration in low birthweight infants with rickets and its response to vitamin D treatment. Arch Dis Child 1981, 56:628-632.

18. Harris EF, Barcroft BD, Haydar S, Haydar B: Delayed tooth formation in low birthweight African-American children. Pediatr Dent 1993, 1 5:30-35.

19. Seow WK, Brown JP, Tudehope DI, O'Callaghan M: Developmental defects in the primary dentition of low birth-weight infants: adverse effects of laryngoscopy and prolonged endotracheal intubation. Pediatr Dent 1984, 6:28-31.

20. Burns $Y$, Rogers $Y$, Neil M: Development of oral function in preterm infants. Physiother Pract 1987, 3:168-178.

21. Rickards AL, Ford GW, Kitchen WH, Doyle LW, Lissenden JV, Keith CG: Extremely-low-birthweight infants: neurological, psychological, growth and health status beyond five years of age. Med J Aust 1987, 147:476-48I.

22. Eight-year outcome in infants with birth weight of $\mathbf{5 0 0}$ to 999 grams: continuing regional study of 1979 and 1980 births. 
Victorian Infant Collaborative Study Group. J Pediatr |991, I I 8:76I-767.

23. Escobar GJ, Littenberg B, Petitti DB: Outcome among surviving very low birthweight infants: a meta-analysis. Arch Dis Child 1991, 66:204-21।.

24. Fadavi S, Adeni S, Dziedzic K, Punwani I, Vidyasagar D: The oral effects of orotracheal intubation in prematurely born preschoolers. ASDC J Dent Child 1992, 59:420-424.

25. Leighton BC: A preliminary study of the morphology of the upper gum pad at the age of 6 months. Swed Dent J 1982:115-122.

26. McCormick MC: The contribution of low birth weight to infant mortality and childhood morbidity. N Engl J Med 1985, 3 I 2:82-90.

27. Kim Seow W, Tudehope DI, Brown JP, O'Callaghan M: Effect of neonatal laryngoscopy and endotracheal intubation on palatal symmetry in two- to five-year old children. Pediatr Dent 1985, 7:30-36.

28. Morris KM, Seow WK, Burns YR: Palatal measurements of prematurely born, very low birth weight infants: comparison of three methods. Am J Orthod Dentofacial Orthop 1993, 103:368-373.

29. Viscardi RM, Romberg E, Abrams RG: Delayed primary tooth eruption in premature infants: relationship to neonatal factors. Pediatr Dent 1994, 16:23-28.

30. Davidson S, Schrayer A, Wielunsky E, Krikler R, Lilos P, Reisner SH: Energy intake, growth, and development in ventilated verylow-birth-weight infants with and without bronchopulmonary dysplasia. Am J Dis Child 1990, 144:553-559.

31. Hack M, Breslau N, Weissman B, Aram D, Klein N, Borawski E: Effect of very low birth weight and subnormal head size on cognitive abilities at school age. N Engl] Med I99I, 325:23 I-237.

32. Vaucher YE, Harker L, Merritt TA, Hallman M, Gist K, Bejar R, Heldt GP, Edwards D, Pohjavuori M: Outcome at twelve months of adjusted age in very low birth weight infants with lung immaturity: a randomized, placebo-controlled trial of human surfactant. J Pediatr 1993, I 22:126-132.

33. Bosma JF: Examination of the mouth and pharynx of the infant. In Proceedings: The comprehensive management of infants at risk for CNS deficits Edited by: Heriza C. Department of Medical Allied Health Professions, University of North Carolina, Chapel Hill; 1974.

34. Palmer $B$ : The influence of breast feeding on the development of the oral cavity. J Hum Lactat 1998, 14:93-98.

35. Pirttiniemi P, Grön M, Alvesalo L, Heikkinen T, Osborne R: Relationship of difficult forceps delivery to dental arches and occlusion. Pediatr Dent 1994, 16:289-293.

36. Paulsson L, Bondemark L, Soderfeldt B: A systematic review of the consequences of premature birth on palatal morphology, dental occlusion, tooth-crown dimensions, and tooth maturity and eruption. Angle Orthod 2004, 74:269-279.

37. Jones DR: Meta-analysis of observational epidemiological studies: a review. J $R$ Soc Med 1992, 85: I65-I68.

38. Derks A, Katsaros C, Frencken JE, van't Hof MA, Kuijpers-Jagtman AM: Caries-inhibiting effect of preventive measures during orthodontic treatment with fixed appliances. A systematic review. Caries Res 2004, 38:413-420.

39. O'Neill J: Little evidence exists about optimal caries-prevention strategies during orthodontic treatment. Evid Based Dent 2004, 5:97.

40. Lagravere MO, Major PW, Flores-Mir C: Long-term dental arch changes after rapid maxillary expansion treatment: a systematic review. Angle Orthod 2005, 75:155-16I.

41. Lagravere MO, Major PW, Flores-Mir C: Skeletal and dental changes with fixed slow maxillary expansion treatment: a systematic review. J Am Dent Assoc 2005, I36:194-199.

42. Hunt $O$, Burden D, Hepper P, Johnston C: The psychosocial effects of cleft lip and palate: a systematic review. Eur J Orthod 2005, 27:274-285.

43. Benson PE, Shah AA, Millett DT, Dyer F, Parkin N, Vine RS: Fluorides, orthodontics and demineralization: a systematic review. J Orthod 2005, 32:102-1 I4.

44. Greenhalgh T: How to read a paper. The medline database. BMJ 1997, 3 I 5: I80-183.

45. Greenhalgh T: How to read a paper. Papers that summerize other papers [systemtic reviews and meta-analyses]. BM] 1997, 315:672-675.
46. Stamm T, Hohoff A: Nonlinear behavior of search strategies for identifying relevant orthodontic articles. Angle Orthod 2004, 74:316-318.

47. Ashley-Montagu MF: The form and dimension of the palate in the newborn. Int J Orthod Dent Child 1934, 20:694-827.

48. Hall J, Froster-Iskenius U, Allanson J: Handbook of normal physical measurements Oxford, New York, Toronto: Oxford University Press; 1989.

49. Miethke R: Zur intrauterinen Entwicklung der Kiefer und Lippen bei menschlichen Feten von der 17. bis zur 42. Woche. In Habilitationsschriften der Zahn- Mund and Kieferheilkunde Berlin: Quintessenz Verlags-GmbH; 1979.

50. Clinch L: Variations in the mutual relationships of the maxillary and mandibular gum pads in the newborn child. Int J Orthod 1934, 20:359-374.

5I. Sillman JH: Relationship of maxillary and mandibular gum pads in the newborn infant. Am J Orthodont Oral Surg 1938, 24:409-424.

52. Hanson JW, Smith DW, Cohen MMJ: Prominent lateral palatine ridges: developmental and clinical relevance. J Pediatr 1976, 89:54-58.

53. Behrstock B, Ramos A, Kaufman N: Does prolonged oral intubation contribute to medical hypertrophy of the lateral palatine ridges and possibly to iatrogenic cleft palate? J Pediatr 1977, $91: 171$

54. Klemke B: Über Kieferform und Bisslage beim Neugeborenen. Med Diss Bonn 1939.

55. Neumann M: Kieferbezügliche Untersuchungen und Messungen an Neugeborenen. Med Diss Kiel 1953.

56. Ott $\mathrm{H}$ : Beitrag zur normalen Entwicklung des Milchgebisses von der Geburt bis zu ca. drei Jahren (anhand von ca. 463 Untersuchungsfällen). Med Diss Leipzig I96I.

57. Erenberg A, Nowak AJ: Appliance for stabilizing orogastric and orotracheal tubes in infants. Crit Care Med 1984, I2:669-67।.

58. Bakwin $\mathrm{H}$, Bakwin R: Form and dimension of the palate during the first year of life. Int J Orthod 1936, 22:1018-1024.

59. Donley CL, Nelson LP: Comparison of palatal and alveolar cysts of the newborn in premature and full-term infants. Pediatr Dent 2000, 22:32I-324

60. Cataldo $E$, Berkman MD: Cysts of the oral mucosa in newborns. Am J Dis Child 1968, I 16:44-48.

6I. Jorgenson RJ, Shapiro SD, Salinas CF, Levin LS: Intraoral findings and anomalies in neonates. Pediatrics 1982, 69:577-582.

62. Dittrich I: Untersuchungen über Form and Größe des Neugeborenen - Oberkiefers anhand von 1000 eigens gewonnenen Modellen. Med Diss Leipzig 1959.

63. Oelschlägl S: Gestaltuntersuchungen an Oberkiefermodellen von 1000 Neugeborenen unter Berücksichtigung des Geschlechtsunterschiedes und der Beziehung zum Kopfindex. Med Diss Leipzig 1954.

64. Leighton B, Seshadri B: A comparison of the gum pads of AfroCaribbean and Caucasian British subjects at birth. Br J Orthod 1990, 17:215-221.

65. Huddart A, Graf B: The maxillary arch dimensions of English, Swiss and Italian normal children at birth and $\mathbf{4}$ months. Are there national differences? In What is cleft lip and palate? A multidisciplinary update; proceedings of an advanced workshop Edited by: Kriens O. Stuttgart: Thieme; 1987.

66. Friend GW, Harris EF, Mincer HH, Fong TL, Carruth KR: Oral anomalies in the neonate, by race and gender, in an urban setting. Pediatr Dent 1990, I2:157-161.

67. Leighton BC: Morphologische Variationen der Alveolarbögen beim Neugeborenen. Fortschr Kieferorthop 1976, 37:8-14.

68. Monteleone L, Mclellan MS: Epstein's pearls (Bohn's nodules) of the palate. J Oral Surg Anesth Hosp Dent Serv 1964, 22:30I-304.

69. Fromm A: Epstein's pearls, Bohn's nodules and inclusion-cysts of the oral cavity. J Dent Child 1967, 34:275-287.

70. Nowak AJ, Casamassimo PS: Oral opening and other selected facial dimensions of children 6 weeks to 36 months of age. Oral Maxillofac Surg 1994, 52:845-847.

7I. Kent SE, Rock WP, Nahl SS, Brain DJ: The relationship of nasal septal deformity and palatal symmetry in neonates. J Laryngol Otol 1991, 105:424-427.

72. Deffez JP, Plante P: The maxilla of infants. Rev Stomatol Chir Maxillofac 1976, 77:403-408. 
73. Cohen JT: Growth and development of the dental arches in children. J Am Dent Assoc 1940, 27: I250-1260.

74. Gray LP: Deviated nasal septum. Incidence and etiology. Ann Otol Rhinol Laryngol Suppl 1978, 87:3-20.

75. Hofbauer K: Haben Geburtslage und Geburtstrauma Einfluss auf die Entstehung von Regelwidrigkeiten des Gebisses, insbesondere der Bisslage? Dtsch Zahn- Mund- und Kieferheilkunde 1943, 19:356-368.

76. Gray LP, Dillon PI, Brogan WF, Henry PJ: The development of septal and dental deformity from birth. Angle Orthod 1982, 52:265-278.

77. Gray LP: The development and significance of septal and dental deformity from birth to eight years. Int J Pediatr Otorhinolaryngol 1983, 6:265-277.

78. Alkan L: Gewisse Formen des harten Gaumens und ihre Entstehung. Arch Laryng Rhin 1990, 10:441-463.

79. Brawley RE, Sedwick HJ: Studies concerning the oral cavity and saliva. I. Palate (2). Palatal measurements. Am J Orthod Oral Surg 1939, 25: 1062-1068.

80. Channing W, Wissler C: Comparative measurements of the hard palate in normal and feeble minded individuals. A preliminary report. Am J Insan 1905, 61:687-697.

81. Delaire J: Considérations sur l'accroissement du pré-maxillaire chez l'homme. Rev Stomatol Chir Maxillofac 1974, 75:95I-970.

82. Denzer BS: The size of the infantile palate. Am J Dis Child I92I, 22:47I-476.

83. Denzer BS: The size of the infantile palate. Int J Orthodont Oral Surg Radiography 1922, 8:510-5I5.

84. Franke G: Über Wachstum und Verbildungen des Kiefers und der Nasenscheidewand aufgrund vergleichender Kiefermessungen und experimenteller Untersuchungen über Knochenwachstum. Zeitschr f Laryng Rhin Otol 1922, 10:187-201.

85. Freiband B: Growth of the palate in the human fetus. J Dent Res 1937, 16:103-122

86. Friel $\mathrm{S}$ : The development of ideal occlusion of the gum pads and the teeth. Am J Orthodont 1937, 40:196-227.

87. Heckmann U, Brune K, Grabowsky R: Über das Breitenwachstum der Kiefer. Dtsch Stomat 1969, 19:759-766.

88. Hoffer O: Entwicklungsbezügliche Feststellungen am Kauorgan von Föten and Neugeborenen. Fortschritte der Kieferorthopädie 1956, 17:166-176.

89. Huddart AG, Clarke J, Thacker T: The application of computers to the study of maxillary arch dimensions. Brit Dent J I97I, 130:397-404.

90. Huddart AG, MacCauley FJ, Davis MEH: Maxillary arch dimensions in normal and unilateral cleft palate subjects. Cleft Palate J 1969, 6:47|-487.

91. Katz J: Über die Gaumenform beim Neugeborenen. Med Diss Frankfurt 1923.

92. Kopra DE, Davis EL: Prevalence of oral defects among neonatally intubated 3- to 5- and 7- to 10-year old children. Pediatr Dent 1991, 13:349-355.

93. Lang J, Baumeister R: Postnatale Entwicklung der Gaumenbreite und -höhe und die Foramina palatina. Anat Anz Jena 1984 , 155:151-167.

94. Lavelle CLB: The shape of the dental arch. Am J Orthod 1975, 67:176-184

95. Lebret L: Growth changes of the palate. J Dent Res 1962, 4I:|39|-|404

96. Lebret L: Der menschliche Gaumen: Sein Wachstum, die auf inn bezogene Wanderung der Seitenzähne, seine Expansion bei Anwendung zweier verschiedener orthodontischer Behandlungsmethoden. Fortschr Kieferorthop 1966, 27: I2I-I 40.

97. Macey-Dare LV, Moles DR, Evans RD, Nixon F: Long-term effect of neonatal endotracheal intubation on palatal form and symmetry in 8-II-year-old children. Eur J Orthod 1999, 21:703-7I0

98. Melsen B: Palatal growth studies on human autosy material. A histologic microradiographic study. Am J Orthod 1975, 68:42-54.

99. Melsen B, Melsen F: The postnatal development of the palatomaxillary region studied on human autopsy material. Am J Orthod 1982, 82:329-432.

100. Mithke RR: Die Oberkieferformen menschlicher Feten vom 5. bis zum I0. Lebensmonat. ZWR 1979, 88:948-95I.
I0I. Miotti F, Miotti A, Drusini A: Sagittal dimensions of the anterior cranial base, maxilla and mandibular body in newborn male infants. Eur J Orthod 1983, 5:245-248.

102. Peyton WT: The dimension and growth of the palate in the normal infant and in the infant with gross maldevelopment of the upper lip and palate. Arch Surg 193I, 22:704-706.

103. Poswillo D: Observations of fetal posture and causal mechanisms of congenital deformity of palate, mandible and limbs. J Dent Res 1966, 45:584-596.

104. Redman RS, Shapiro BL, Gorlin RJ: Measurement of normal and reportedly malformed palatal vaults. II. Normal juvenile measurements. I Dent Res 1966, 45:266-269.

105. Schulze C: Die normale and abnorme Entwicklung des Gebisses. Die Umbauvorgänge im Parodontium and Kiefergelenksbereich. Morpho- bzw. Pathogenese and Atiologie der Dysgnathien 2nd edition. No. 3 in Lehrbuch der Kieferorthopädie, Berin, Chicago, London, Sao Paulo, Tokio: Quintessenz Verlags-GmbH; 1993.

106. Sillman JH: Dimensional changes of the dental arches: Longitudinal study from birth to 25 years. Am J Orthod 1964, 50:824-842.

107. Angelos GM, Smith DR, Jorgenson R, Sweeney EA: Oral complications associated with neonatal oral tracheal intubation: a critical review. Pediatr Dent 1989, I I:I33-140.

108. Kahl-Nieke B: Einführung in die Kieferorthopädie München: Urban \& Schwarzenberg; 1995

109. Ginoza G, Cortez S, Modanlou HD: Prevention of palatal groove formation in premature neonates requiring intubation. J Pediatr 1989, II 5:133-135.

I I0. Howell S: Assessment of palatal height in children. Community Dent Oral Epidemiol 198I, 9:44-47.

III. Robke E: Die Gaumenplatte nach Castillo Morales and ihre Wirkung auf die Gaumenentwicklung von Säuglingen mit Trisomie 2l im Vergleich zu gesunden Säuglingen. Zahnmed Diss Münster 1998.

Publish with BioMed Central and every scientist can read your work free of charge

"BioMed Central will be the most significant development for disseminating the results of biomedical research in our lifetime. "

Sir Paul Nurse, Cancer Research UK

Your research papers will be:

- available free of charge to the entire biomedical community

- peer reviewed and published immediately upon acceptance

- cited in PubMed and archived on PubMed Central

- yours - you keep the copyright
BioMedcentral 